\title{
The regional machine-building complex: structural-industrial transformation in modern economic realities
}

\author{
Evgeniy Semenov ${ }^{1,2}$, Alexandr Pishchukhin ${ }^{2, *}$ and Gulnara Akhmedyanova ${ }^{2}$ \\ ${ }^{1}$ Institute of the Steppe, Ural Branch of the Russian Academy of Sciences, Pionerskaya St., 11, \\ ${ }^{2}$ Orenburg state University, Aerospace Institute, 460018 Orenburg, Russia
}

\begin{abstract}
The work is devoted to the analysis of the development of machine-building complex in the Orenburg region. The main problems of regional engineering are associated with a constant investment deficit and the scarcity of financing programs aimed at modernization and innovative technical and technological updating of the engineering complex. The potential of small enterprises in high-tech industries is very high. These industries require the use of highly skilled labor, including researchers and scientists, which is very important for the preservation and development of the intellectual capital of the region. Small business in mechanical engineering is able to make a powerful leap forward in improving the business sector as a whole. A significant problem of regional engineering is the marked predominance of industrial engineering products and the extremely weak availability of engineering products for the population. In order to correct this imbalance, it is necessary to place engineering industries in small and medium-sized cities: Buzuluk, Buguruslan, Sorochinsk, Kuvandyk, Sol-Iletsk, Abdulino, which have a favorable transport position and favorable conditions for specialization and cooperation. In these centers at small enterprises, it is possible to organize the production of consumer engineering products, as well as components based on cooperation with larger engineering enterprises.
\end{abstract}

\section{Introduction}

Until the 40s of the 20th century, a number of small machine-building industries operated in the orenburg region, mainly related to the repair of agricultural machinery and rolling stock of railway transport. During the Great Patriotic war, the equipment of about 100 enterprises was evacuated to the region, including engineering, and subsequently their production capacities became the basis for the formation of the engineering industry of the orenburg region [1]. On their material and technical/technological basis, such industries as machine tool construction, heavy and agricultural engineering, and military-industrial complex production arose.

Further development of the machine-building complex of the region fit into the outline

\footnotetext{
* Corresponding author: pishchukhin55@mail.ru
} 
of the planned principles for the distribution of productive forces and the formation of territorial production complexes. So, based on the raw material factor (the presence of regional metallurgical industries and the proximity of the enterprises of the ural metallurgical base) and the consumer factor (proximity to large centers of ferrous and nonferrous metallurgy, oil and mining enterprises of the Ural and the Volga region), heavy machine building and machine tool building have received large-scale development. Provision of qualified and scientific personnel formed the line of production of knowledgeintensive and labor-intensive engineering and the military-industrial industry.

The favorable transport and geographical position of the region on important communication lines connecting Central Russia, the Volga region and the Urals with Siberia, Kazakhstan and Central Asia provided wide logistic opportunities for specialization and cooperation of machine-building production and marketing of finished products.

\section{Historical dynamics}

By 1990, mechanical engineering was listed as one of the specialization sectors of the Orenburg region. In the industrial structure of production, in terms of cost of marketable products, it was only slightly inferior only to the fuel and energy complex [2, p.27].

By the beginning of the 2000s, the value of the machine-building complex in the industrial circuit of the region had significantly decreased. By 2005, its share in the structure of industry decreased by more than three times (Table 1). During this period, the production of once-known types of products of machine-tool industry (metal-cutting machines), the electrical industry (electrical converters, refrigeration equipment, vacuum cleaners, washing machines), agricultural machinery (units and components for fodder harvesting equipment, mills and elevators), and the tool industry failed in the region. (production of drills). Dramatically reduced production output in almost all existing facilities of the complex (Table 1). The declared conversion at the enterprises of the military-industrial complex, also did not bring tangible results [3], [1, p.235], [4].

Table 1. The specific gravity and production of the main types of products of the engineering complex of the Orenburg region [5], [6], [7], [8], [9].

\begin{tabular}{|l|c|c|c|c|c|c|}
\hline Indicators / Years & 1990 & 2000 & 2005 & 2010 & 2015 & 2018 \\
\hline $\begin{array}{l}\text { machine-building complex share in the } \\
\text { structure of industrial production,\% }\end{array}$ & 23,1 & 9,2 & 6,9 & 6,1 & 6,0 & 4,5 \\
\hline $\begin{array}{l}\text { Metallurgical } \\
\text { equipment, thousand tons }\end{array}$ & 21,6 & 7,6 & 10,5 & 11,4 & 12,8 & -- \\
\hline Press forging machines, pcs. & 6091 & 120 & 274 & 616 & 194 & 256 \\
\hline Metal-cutting machines, pcs. & 2618 & 101 & 15 & -- & -- & -- \\
\hline Tractor trailers, pcs. & 23809 & 1709 & 2412 & 1270 & 279 & -- \\
\hline Trailers for trucks, pcs. & 300 & 389 & 217 & 63 & -- & -- \\
\hline $\begin{array}{l}\text { Tractors (assembly) for agriculture and } \\
\text { forestry, pcs. }\end{array}$ & -- & -- & -- & 1191 & 214 & 198 \\
\hline $\begin{array}{l}\text { Electric motors, thousand units } \\
\text { Refrigerators and freezers, thousand } \\
\text { units }\end{array}$ & 520,4 & 211,3 & 227,0 & 133,2 & 85,2 & 60,4 \\
\hline Vacuum cleaners, thousand units & 272,1 & 1,5 & -- & -- & -- & -- \\
\hline
\end{tabular}

Such an impressive drop in machine-building production during these years was primarily due to:

- a sharp decrease in demand for engineering products, when in the conditions of a deregulated market and an open global economy, many types of products of the region's engineering enterprises did not meet modern requirements in terms of quality or assortment 
and could not withstand competition with foreign analogues;

- the presence of outdated technologies at most enterprises, the absence and extreme shortage of financial resources for the modernization of production and technological updating;

- reduction in production volumes and limited working capital in other sectors of the economy for which the machine-building enterprises of the region supplied their products;

- the weakening and, not infrequently, rupture of production and technological ties for specialization and cooperation between enterprises for the supply of raw materials, semifinished products and components in connection with the collapse of the USSR and the entry of counterparties into more attractive markets.

Since the mid-2000s, after not long stabilization, the machine-building complex of the region continued to lose its share in the industrial structure of the region. Despite the implementation of some investment programs for the development of mechanical engineering in the region (commissioning of the car factory in Orsk, assembly production of the model range of Belarus tractors in Buzuluk and agricultural machinery of the John Deere company in Orenburg), the industry continues to reduce production [10], [5]. New capacities also stalled; their products do not find the proper response from consumers. A significant part of enterprises operates in the conditions of constant growth of tariffs of energy supplying organizations, unstable price segment of suppliers and sporadic orders.

Compared to 1990, there was a more than fourfold decrease in the share of the branches of the machine-building complex in the structure of industrial production (Table 1), and the share of machine-building in the structure of manufacturing industries decreased from $33.5 \%$ to $13.6 \%$, including the production of metal products, without $4.5 \%$ of them. In the structure of the entire industry of the region, the share of machinery and equipment is only $1.8 \%[5]$.

\section{Territorial distribution}

In modern economic realities, there is a significant simplification of the structure of regional engineering. The role of complex, labor-intensive, full-cycle machine building (machine tool construction, electrical engineering, production of metallurgical and mining equipment) is narrowing. Metalworking, molding and foundry, assembly and repair industries come to the fore. In the industrial composition of mechanical engineering and metalworking, it is precisely the production of metal products that accounts for $2 / 3$ of the total cost of marketable products of the complex [5].

The main problems of regional engineering are associated with a constant investment deficit and the scarcity of financing programs aimed at modernization and innovative technical and technological updating of the engineering complex. Institutional problems caused by flaws in the formation of the industrial policy of the region and the lack of funds involved in improving the investment attractiveness of the region.

Technical and technological imperfection at many enterprises of the complex continues to worsen. The average depreciation rate of fixed assets in the industry for 2017 is $47-50 \%$. Their renewal coefficient does not exceed $9.5 \%$ per year. Hence low labor productivity, a high level of costs for the production and marketing of products, low efficiency [5].

The low level of market adaptability, innovation, investment activity and attractiveness, the introduction of new creative industries and technologies at most enterprises in the industry does not allow for a qualitative modernization of production, an increase in the share of competitive products in the market, and successful import substitution. The volume of investment in fixed assets of enterprises of the machine-building complex is only 5-6\% of the total array of capital investments in the industrial sector of the Orenburg region. The share of competitive products is only $8-9 \%$ of the total volume of commodity products of 
the manufacturing industry [5].

Despite the shutdown of a number of industries and a reduction in labor personnel, the personnel problem at the existing enterprises of the machine-building complex has become aggravated - a shortage of highly qualified workforce. The average salary of workers at engineering enterprises is $25 \%$ lower than the industry average and 2.2 times lower than in the region's oil and gas sector [12], [5], [9]. This holds back the influx into the engineering industry of professional qualified specialists and workers.

Due to the frequent change of ownership, instability of consumer contracts and orders, engineering enterprises experience an acute shortage of working capital necessary to modernize production and expand the range of competitive products. The use of borrowed funds from credit and financial organizations, due to the instability of the consumer market for engineering products, often leads to non-fulfillment of debt obligations and forces enterprises to lease production facilities and put up for sale liquid equipment in order to pay off debts and avoid bankruptcy.

Despite the much shrunken machine-building complex, it continues to play an important role in shaping the industrial image of the region and, undoubtedly, has a development potential, which is determined by the presence of a metallurgical and consumer base, developed transport infrastructure, qualified personnel, production and technological resources of the military-industrial complex.

As a labor-intensive industry, engineering has a significant impact on the formation of the region's labor market. About 25 thousand employees are involved in the enterprises of the complex, which makes up 15\% of all those employed in the industrial sector of the region. [5]. By the cost of fixed assets, engineering occupies the fourth line in the ranking of regional industries. A wide line of production of the machine-building complex has a high multiplier effect on the development of other industries, being a major consumer of ferrous and non-ferrous metallurgy products, the chemical industry, energy, transport and services.

A number of enterprises in the region's machine-building complex have improved the quality of their products, carried out technical and technological re-equipment, adapted their specialization and are relatively stable in market conditions.

In Orenburg, a drilling equipment factory produces drilling rigs equipped with pipes of special strength, manufactured using a unique technology of pressure welding, which are indispensable in geological exploration and tunneling. Drilling rigs for exploration drilling for solid minerals are our own development of the plant, a vivid example of the implementation of the import substitution program.

Orsk Machine-Building Plant, a leading supplier of drilling locks for oil and gas pipes, has virtually replaced all imported products on drilling locks in the country with its products.

\section{Trends and development paths}

Today, the Orenburg region includes about 60 large and medium enterprises. From this list of the most efficiently and stably functioning, no more than 15 can be distinguished [10].

The Strela production association located in Orenburg is one of the leading enterprises in the country's defense industry and the largest diversified enterprise in the Volga Federal District. The enterprise also produces special-purpose products, assembly components and components, components and parts for the oil and gas industry, for railway transport structures.

Another enterprise of the military-industrial profile "Orsk Mechanical Plant". High quality of products is traditionally for the enterprise.

Orsk Machine-Building Plant is a leading manufacturer of drilling locks for oil and gas 
drilling pipes, and also specializes in the production of cylinders for compressed gases and hydraulic cylinders. Drill lock manufacturing has been certified to international standards.

The Orenburg Radiator enterprise specializes in the production of aluminum and copper-brass radiators for tractors, road-building and agricultural machinery, forklifts, pumping units and mobile power plants adapted for operation in various climatic conditions. The use of new technologies, equipment, composite materials - metal plastics, bimetals, solders and thin tapes ensures high quality and competitive products.

Orenburg Locomotive Repair Plant - a large enterprise, equipped with production facilities for the current and overhaul of trunk and shunting and diesel locomotives. The plant is equipped with a multidisciplinary line, including foundry, tool, assembly and electrical production, which produce more than 100 types of components for diesel locomotives and electric locomotives, and repair rolling stock of railway transport [10].

Mednogorsk enterprise "Uralelectro" specializes in the production of asynchronous electric motors and magnetic starters, low-voltage and communication equipment. The company carried out a technical upgrade of production, which allowed us to master the production and expand the range of electric motors with improved technical parameters.

The Orenburg Inverter Plant, a manufacturer of electric voltage converters, sources and uninterruptible autonomous power supply systems, has mastered the production of importsubstituting products - uninterruptible power supply systems, including 3rd generation uninterruptible power supply units for nuclear power plants. In addition, the company produces a wide range of low-voltage equipment. Modern welding machines manufactured at the enterprise using foreign technologies are in deserved demand.

The Buzuluk Mechanical Plant produces copper-brass cooling and heating radiators for tractors, forklifts, road-building and agricultural machinery, and mobile power plants. The enterprise has mastered the assembly production of Belarus brand tractors of various configurations and capacities, as well as the production of grain seeders and balers.

The Orenburg "Drilling Equipment Plant" specializes in the production of robotic drilling rigs, drill pipes, tools and components for exploration enterprises for the development of solid mineral deposits. The enterprise carried out technical and technological modernization of existing facilities with the improvement of technological processes to increase the productivity of operational work.

Hydropress Orenburg plant specializes in the production of hydraulic presses for various and special purposes, which are used in various sectors of the material production sphere.

Kuvandyk plant "Dolina" produces metalworking and forging equipment, tooling for the construction industry and the agricultural sector, products for utilities.

Orenburg plant "Orstan" specializes in the production of foundry and molding products demanded by oil and gas companies.

A division of the American agricultural-industrial corporation John Deere in Orenburg produces sowing and tillage equipment [5].

The regional government and the expert community developed the regional target program "Modernization of the machine-building complex of the Orenburg region for 2015-2020" in accordance with the course adopted in the Russian Federation for the modernization and innovative nature of the country's economy, as well as in accordance with the development strategy of the Orenburg region until 2020 and for the period until 2030. It proposed a number of constructive measures and tools to overcome the permanent crisis of production in the machine-building complex and bring it to a stabilization and progressive level [11], [13]. In addition to this, we have proposed a number of approaches aimed at overcoming regional engineering from the crisis and its sustainable development.

In order to initiate demand for engineering products, the following measures are possible: engineering support of turnkey production (installation, debugging, maintenance 
of the equipment sold); expansion of leasing; improving the management system, increasing the effectiveness of marketing systems, improving information support, switching to a tender system for the procurement of raw materials, components [14].

Improving the functioning of the region's engineering complex is possible through the development of intra-regional production cooperation and the possibility of creating production clusters with wide integration with the manufacturing and non-manufacturing sectors. In order to increase the efficiency of the process of territorial integration in mechanical engineering, the cooperation of engineering enterprises and organizations in the scientific and technical sphere, state support of technology parks, technology centers, and various regional business associations is important. The introduction of intraregional cooperation in engineering, could lead to positive results on the basis of indicative planning and guaranteed orders of suppliers and consumers [14].

The administrative structures of the region need to form a solid institutional base, which will determine the development strategy of the machine-building complex and the conditions for the activities of regional economic entities, and regulate the problems of state, regional and municipal orders. One of the factors restraining the effectiveness of the work of machine-building branches is the poor alignment of science with production, factories hardly come to their senses after the crisis, equipment is outdated, there are not enough funds for updating, personnel are "isolated" from survival.

The potential of small enterprises in high-tech industries is very high. These industries require the use of highly skilled labor, including researchers and scientists, which is very important for the preservation and development of the intellectual capital of the region. Small business in mechanical engineering is able to make a powerful leap forward in improving the business sector as a whole.

\section{Conclusion}

A significant problem of regional engineering is the marked predominance of industrial engineering products and the extremely weak availability of engineering products for the population. In order to correct this imbalance, it is necessary to place engineering industries in small and medium-sized cities: Buzuluk, Buguruslan, Sorochinsk, Kuvandyk, Sol-Iletsk, Abdulino, which have a favorable transport position and favorable conditions for specialization and cooperation. In these centers in small enterprises, it is possible to organize the production of consumer engineering products, as well as components based on cooperation with larger engineering enterprises

\section{References}

1. Lapaeva, M.G. Economics of the Orenburg Region (1743-2004): monograph (Orenburg: Gazprom-print 2006) 468 p.

2. Borisyuk, N.K. Reforming economic relations during the transition to the market: on the example of the fuel and energy complex of the Orenburg region (M.: Economics 1997) 286 p.

3. Borisyuk, N.K. The economy of the Orenburg region and the global financial crisis Bulletin of the Orenburg State University 9 (2009) pp 31-35.

4. Lapaeva, M.G. Industrial policy in the region: problems and ways of improvement Bulletin of the Orenburg State University 10 (2004) pp 80-86.

5. Industrial production of the Orenburg region: Stat.sb. The territorial body of the Federal State Statistics Service for the Orenburg Region (Orenburg 2018) 140 p. 
6. Statistical Review of the Orenburg Region: Stat.sb. The territorial body of the Federal State Statistics Service for the Orenburg Region is (Orenburg 2019) $62 \mathrm{p}$.

7. Statistical Yearbook of the Orenburg Region. 2018: Stat. (Orenburgstat. Orenburg 2018) 530 p.

8. Statistical Yearbook of the Orenburg Region. 1998. Orenb.obl.committee of state statistics (Orenburg 1998) 269 p.

9. Statistical Yearbook. Orenburg region - 80 years. 2014: Stat. (Orenburgstat. Orenburg 2014) 566 p.

10. Orenburg region. Portal of the Government of the Orenburg Region. Housekeeper of the area. Industry. http://www.orenburg-gov.ru/Info / Economics / Industry /

11. Decree of the Government of the Orenburg region of 07.30.2013; NGR RU56000201300944

12. Orenburg region: Stat.sb. Territorial authority of the Federal State Statistics Service for the Orenburg Region (Orenburg 2013) 477 p.

13. The development strategy of the Orenburg region until 2030. [Electronic resource] Electronic data - M .; Ministry of Regional Development, 2013. - Access mode: http: //www.orb.ru/

14. Chibilev A.A. (jr.), Semenov E.A. Essays on the economic geography of the Orenburg Territory (I Yekaterinburg: LLC UZAO, 2014) 182 p. 